\title{
EFEKTIVITAS TEH HIJAU DAN SARI KACANG HIJAU DALAM MENURUNKAN KADAR KOLESTEROL TOTAL PADA PENGGUNA KONTRASEPSI SUNTIK PROGESTIN
}

\author{
Fazdria* \\ *Prodi Kebidanan Langsa Poltekkes Kemenkes Aceh \\ E-mail : fadzria@poltekkesaceh.ac.id
}

\begin{abstract}
ABSTRACT THE EFFECTIVENESS OF GREEN TEA AND GREEN BEAN EXTRACT IN REDUCING TOTAL CHOLESTEROL LEVELS IN PROGESTIN INJECTABLE OF CONTRACEPTION USERS
\end{abstract}

Background: Hypercholesterolemia is a condition of increasing total cholesterol level $\geq 200 \mathrm{mg} / \mathrm{dl}$ and has a close relationship with the severity of atherosclerosis or the emergence of heart disease in the blood vessels which is one of the factors in the occurrence of heart and cardiovascular disease. Hypercholesterolemia can be overcome by consuming green tea and green bean juice. This study was conducted to determine the effect of green tea and green bean extract in reducing cholesterol levels in DMPA family planning users.

Purpose: To determine the effect of green tea and green bean extract on total cholesterol levels in DMPA family planning acceptors

Methods: The design of this study was a quasi-experimental study with a pretest-posttest control group design approach, namely data collection was carried out before and after treatment. The research subjects were 24 DMPA family planning users according to the inclusion criteria and grouped into 4 groups (control, green tea, green bean extract and a combination of green tea and green bean extract).

Results: There was a difference in mean cholesterol levels between pretest and posttest in the mung bean extract group from $252 \mathrm{mg} / \mathrm{dl}$ decreased to $179.83 \mathrm{mg} / \mathrm{dl}$ and the combination of green tea and mung bean juice decreased from $259.17 \mathrm{mg} / \mathrm{dl}$ decreased to $212.33 \mathrm{mg} / \mathrm{dl}$. However, there was no significant mean difference between pretest and posttest cholesterol levels in the control group and the green tea treatment group

Conclusion: Green tea and green bean juice consumed separately can reduce cholesterol levels in DMPA family planning acceptors

Suggestion Further research is needed to control confounding factors such as daily diet.

Keywords: DMPA, cholesterol, green beans, green tea

\section{ABSTRAK}

Latar Belakang : Hiperkolesterolemia merupakan suatu keadaan peningkatan kadar kolesterol total $\geq 200$ $\mathrm{mg} / \mathrm{dl}$ dan mempunyai hubungan yang erat dengan keparahan aterosklerosis atau timbulnya panyakit jantung di saluran pembuluh darah yang menjadi salah saru faktor terjadinya penyakit jantung dan kardiovaskuler. Hypercholesterolemia bisa diatasi dengan mengkonsumsi teh hijau dan sari kacang hijau. Penelitian ini dilakukan untuk mengetahui pengaruh teh hijau dan sari kacang hijau dalam menurunkan kadar kolesterol pada pengguna KB DMPA.

Tujuan : Untuk mengetahui pengaruh teh hijau dan sari kacang hijau terhadap kadar kolesterol total pada akseptor KB DMPA

Metode : Rancangan penelitian ini adalah quasi eksperimen dengan pendekatan pretest posttest control group design yaitu pengumpulan data dilakukan sebelum dan sesudah perlakuan. Subjek penelitian adalah pengguna KB DMPA sesuai kriteria inklusi yang berjumlah 24 orang dan dikelompokkan dalam 4 kelompok (kontrol, teh hijau, sari kacang hijau dan kombinasi teh hijau dan sari kacang hijau).

Hasil : Terdapat perbedaan rerata kadar kolesterol antara pretest dan posttest pada kelompok sari kacang hijau dari $252 \mathrm{mg} / \mathrm{dl}$ turun menjadi $179.83 \mathrm{mg} / \mathrm{dl}$ dan kombinasi teh hijau dan sari kacang hijau turun dari $259.17 \mathrm{mg} / \mathrm{dl}$ turun menjadi $212.33 \mathrm{mg} / \mathrm{dl}$. Namun tidak ada perbedaan rerata yang signifikan kadar kolesterol pretest dan posttest pada kelompok kontrol dan kelompok perlakuan teh hijau.

Kesimpulan : Teh hijau dan sari kacang hijau yang dikonsumsi secara terpisah mampu menurunkan kadar kolesterol pada ibu akseptor KB DMPA. 


\section{JKM (Jurnal Kebidanan Malahayati),Vol 7,No.3.Juli 2021, ISSN (Print) 2476-8944 ISSN (Online) 2579-762X, Hal 376-382}

Saran Perlu dilakukan penelitian lanjutan dengan mengontrol faktor perancu seperti pola makan seharihari.

Kata Kunci : KB DMPA, Kolesterol, Kacang hijau, Teh Hijau

\section{PENDAHULUAN}

Tingginya

(hiperkolesterolemia) merupakan faktor risiko utama penyebab penyakit jantung. Kelebihan kolesterol akan bereaksi dengan zat-zat lain dan mengendap dalam pembuluh darah arteri pada akhirnya akan menyebabkan terjadinya arterosklerosis sehingga mengganggu proses sirkulasi darah ke jantung (Fernández-Friera et al., 2017) . Menurut data profil Penyakit Tidak menular (PTM) 2016 jumlah prevalensi penderita kolesterol tinggi yaitu laki-laki sebesar $48 \%$ sedangkan pada perempuan $54.3 \%$. Prevalensi tersebut mayoritas pada usia $>60$ tahun $(58,7 \%)$, usia $35-59$ tahun $(52,9 \%)$ dan usia $15-34$ tahun $39,4 \%$ (Kemenkes $\mathrm{RI}, 2017)$. Hal ini juga didukung hasil Riset kesehatan dasar (Riskesdas) tahun 2018 memperlihatkan bahwa prevalensi penyakit pembuluh darah seperti hipertensi yaitu sebesar $34,1 \%$ per 1000 penduduk (Riskesdas, 2018). Prevalensi hypercholesterolemia lebih banyak pada wanita dibandingkan pria. Hal ini salah satu nya disebabkan metode KB yang banyak dipilih oleh wanita adalah KB hormonal yaitu DepoMedroxyprogesteron Acetat (DMPA) atau yang sering dikenalnya adalah Depo progestin. Kadar kolesterol pada pengguna kontrasepsi suntik progestin berhubungan dengan lamanya pemakaian kontrasepsi tersebut (Prasetyorini et al., 2021; Prawerti et al., 2019).

Wanita pengguna depo progestin lebih beresiko terjadi peningkatan berat badan, yang diakibatkan oleh akumulasi lemak terutama lemak viseral. Hal tersebut disebabkan karena tubuh mengalami penurunan kadar esterogen sehingga memicu terjadinya obesitas dan peningkatan lemak viseral pada obesitas terpengaruh oleh perubahan hormon leptin yang berfungsi pengatur nafsu makan (Wahyuni \& Putri, 2017). Untuk mangantisipasi kondisi negatif akibat efek samping penggunaan Depo progestin pada akseptor KB, salah satunya adalah menggunakan teh hijau (Camellia sinensis) (Maydawati \& Veri, 2020).

Teh hijau bermanfaat sebagai anti inflamasi dan anti proliferasi sehingga menyebabkan teh hijau termasuk dalam suplemen diet dan berfungsi sebagai minuman (Rahayu et al., 2015). Mekanisme pencegahan penyakit kardiovaskuler terdapat juga pada kemampuan teh hijau dalam menghambat penyerapan kolesterol dan menghambat penggumpalan sel-sel platelet. Polifenol teh (katekin dan theaflavin) juga merupakan antioksidan kuat yang mampu melindungi oksidasi LDL kolesterol oleh radikal bebas (Hardani et al., 2014). Hal ini juga didukung dengan hasil penelitian bahwa terdapat perbedaan yang signifikan kadar kolesterol antara kelompok perlakuan dan kelompok kontrol setelah pemberian teh hijau (Fazdria, 2020). Selain teh hijau Faktorfaktor yang dapat menurunkan kadar kolesterol adalah mengurangi asupan lemak dan kolesterol, olah raga teratur dan memilih makanan yang mengandung isoflavon. Isoflavon merupakan salah satu jenis flavonoid yang terbukti dapat mengatur lipogenesis dihati. Isoflavon jenis genistein dan deidzein banyak terdapat dalam kacang kacangan seperti kacang hijau (vigna radiata) dan kacang kedelai (arachis hypogaea). Genistein dapat menghambat produksi hidrogen peroksida dan meningkatkan aktivitas enzim antioksidan, seperti katalase, peroksida dismutase, glutation peroksidase, dan glutation reduktase. Low Density Lipoprotein (LDL) yang berinteraksi dengan isoflavon akan terjadi penurunan oksidasi lipoprotein dan menekan pembentukan lipid peroksida dan zat - zat reaktif asam tiobarbiturat. Mekanisme penurunan kadar kolesterol oleh isoflavon dengan meningkatkan katabolisme sel lemak dalam pembentukan energi yang mengakibatkan turunnya kadar kolesterol total (Steyers \& Miller, 2014). Beberapa penelitian mengenai pemberian jus kacang hijau pada wanita hiperkolesterolemia yang dikonsumsi $400 \mathrm{ml} /$ hari selama 14 hari telah terbukti dapat menurunkan kolesterol total (Maulidya et al., 2018; Munabari \& Ikawati, 2018).

\section{METODOLOGI PENELITIAN}

Rancangan penelitian ini adalah quasi eksperimen dengan pendekatan pretest posttest control group design yaitu pengumpulan data dilakukan sebelum dan sesudah perlakuan. Pada pengujian data pretest dilakukan 1 hari sebelum diberikan perlakuan selanjutnya dilakukan pemberian teh hijau dan sari kacang hijau pada kelompok intervensi selama 14 hari berturut - turut, pada hari ke 15 dilakukan posttest pengumpulan data dengan melihat kadar kolesterol total pada 
akseptor KB DMPA diwilayah kerja UPTD Puskesmas Langsa Baro tahun 2020 yang melibatkan 3 kelompok intervensi dan 1 kelompok kontrol. Nilai kadar kolesterol total ibu akseptor KB DMPA yang di ukur melalui pemeriksaan dengan menggunakan strip test pada kelompok teh hijau, sari kacang hijau, teh hijau ditambah sari kacang hijau dan kelompok kontrol. Dilakukan sebanyak dua kali yaitu sebelum dan sesudah perlakuan. Pemberian seduhan teh hijau sebanyak $2.4 \mathrm{gr} / \mathrm{hari}$ (selama 14 hari pada akseptor KB DMPA. Sari kacang hijau sebanyak $400 \mathrm{ml} / \mathrm{hari}$ diberikan selama 14 hari pada akseptor KB DMPA. Responden dipilih sesuai denga kriteria inklusi yang berjumlah 24 orang.

\section{HASIL DAN PEMBAHASAN}

Berdasarkan hasil penelitian yang dilakukan di Desa Karang Anyar Kec. Langsa Baro Kota Langsa dari tanggal 1 s/d 18 Oktober 2020 pada 24 orang responden, maka didapatkan hasil sebagai berikut :

Tabel 1.

Distribusi Frekuensi Karakteristik Responden

\begin{tabular}{lcccccc}
\hline \multicolumn{1}{c}{ Variabel } & Kontrol & Teh Hijau & $\begin{array}{c}\text { Sari Kacang } \\
\text { Hijau }\end{array}$ & $\begin{array}{c}\text { Kombinasi Teh } \\
\text { Hijau dan Sari } \\
\text { Kacang Hijau }\end{array}$ & Jumlah & $\%$ \\
\hline $\begin{array}{l}\text { Umur } \\
<25 \text { th }\end{array}$ & 0 & 2 & 0 & 0 & 2 & 8.33 \\
$\begin{array}{l}25-35 \text { th } \\
>35 \text { th }\end{array}$ & 5 & 2 & 6 & 5 & 18 & 75 \\
$\begin{array}{l}\text { Berat Badan } \\
\leq 50 \mathrm{~kg}\end{array}$ & 1 & 2 & 0 & 1 & 4 & 16.67 \\
$\begin{array}{l}51-60 \mathrm{~kg} \\
61-70 \mathrm{~kg}\end{array}$ & 0 & 1 & 0 & 2 & 3 & 12.5 \\
$>70 \mathrm{~kg}$ & 6 & 3 & 3 & 1 & 13 & 54.17 \\
$\begin{array}{l}\text { Pemakaian DMPA } \\
\leq 2 \text { th }\end{array}$ & 0 & 2 & 3 & 2 & 7 & 29.17 \\
$>2$ th & 0 & 0 & 0 & 1 & 1 & 4.16 \\
$\begin{array}{l}\text { Paritas } \\
\leq 3\end{array}$ & 3 & 2 & 2 & 5 & 12 & 50 \\
$>3$ & 3 & 4 & 4 & 1 & 12 & 50 \\
\hline \multicolumn{1}{l}{ Jumlah } & 5 & 6 & 4 & 6 & 21 & 87.5 \\
\hline
\end{tabular}

Pada tabel diatas tampak bahwa mayoritas responden dalam penelitian ini adalah berusia 2535 tahun 18 responden (75\%), memiliki berat badan 51-60 kg sebanyak 13 responden (54.17\%), ratarata lama pemakaian DMPA adalah seimbang antara 1-2 tahun dan diatas 2 tahun masing-masing 12 orang responden (50\%) dan mayoritas sudah pernah melahirkan 1-3 kali sebanyak 1-2 orang sebanyak 21 responden (87.5\%). Dari data karakteristik tidak terdapat perbedaan yang ekstrim mencakup umur, berat badan, lama pemakaian DMPA dan paritas dikarenakan sudah dijadikan kriteria inklusi dalam pemilihan sampel.

Tabel 2.

Perbedaan rata-rata kadar kolesterol sebelum dan sesudah perlakuan pada kelompok responden

\begin{tabular}{lccc}
\hline \multirow{2}{*}{ Kelompok Responden } & \multicolumn{2}{c}{ Rerata \pm SD } & \multirow{2}{*}{ Sig. } \\
\cline { 2 - 3 } & Pretest & Posttest & \\
\hline Kontrol & $237 \pm 45.21$ & $234 \pm 61.06$ & 0.891 \\
Teh Hijau & $233 \pm 51.13$ & $193 \pm 34.10$ & 0.079 \\
Sari kacang hijau & $252 \pm 36.72$ & $179 \pm 58.14$ & 0.003 \\
Teh hijau + sari kacang hijau & $259 \pm 28.05$ & $212 \pm 54.63$ & 0.043 \\
\hline
\end{tabular}




\section{JKM (Jurnal Kebidanan Malahayati),Vol 7,No.3.Juli 2021, \\ ISSN (Print) 2476-8944 ISSN (Online) 2579-762X, Hal 376-382}

Pada tabel diatas, tampak data rerata kadar kolesterol pada saat pretest dan posttest pada ibu pengguna kontrasepsi DMPA. Pada saat pretest, kadar kolesterol tertinggi terdapat pada kelompok teh hijau dan sari kacang hijau yaitu 259,17 mg/dl dan pada saat posttest kadar kolesterol tertinggi pada kelompok kontrol $234 \mathrm{mg} / \mathrm{dl}$.

Perubahan kadar kolesterol kelompok kontrol antara pretest dan posttest tidak bermakna secara statistic ( $p$-value 0.891). Berikutnya pada kelompok teh hijau, dengan $p$-value 0.079 ( $p$-value $>0.05$ ) yang berarti perbedaan kadar kolesterol antara sebelum dan sesudah perlakuan teh hijau juga tidak bermakna secara signifikan. Namun untuk perlakuan sari kacang hijau tampak $p$-value 0.003 , yang berarti sari kacang hijau mampu menurunkan kadar kolesterol total akibat penggunaan KB DMPA dan untuk perlakuan teh hijau yang dikombinasi dengan sari kacang hijau menunjukkan $p$-value 0.043 artinya perlakuan teh hijau dan sari kacang hijau secara bersama-sama mampu menurunkan kadar kolesterol total secara signifikan.

Tabel 3.

Hasil uji multivariate

\begin{tabular}{llcc}
\hline Kelompok & & Sig. & Partial Eta Squared \\
\hline Kontrol & Wilks' lambda & 0.891 & 0.001 \\
Teh Hijau & Wilks' lambda & 0.079 & 0.146 \\
Sari Kacang Hijau & Wilks' lambda & 0.003 & 0.357 \\
Teh Hijau + Sari Kacang Hijau & Wilks' lambda & 0.043 & 0.189 \\
\hline
\end{tabular}

Pada tabel diatas, pada kelompok yang bermakna secara statistic perbedaan kadar kolesterol yaitu kelompok perlakuan sari kacang hijau dan teh hijau + sari kacang hijau, didapatkan nilai partial eta pada kolom Wilks' Lambda 0.357 yang berarti dari kacang hijau yang diberikan menurunkan kadar kolesterol sebesar 35.7\% dan pada kelompok kombinasi teh hijau dan sari kacang hijau mampu menurunkan kadar kolesterol sebesar $18.9 \%$. Artinya pemberian sari kacang hijau secara terpisah mampu menurunkan kadar kolesterol lebih efektif dibandingkan kelompok lain.

\section{PEMBAHASAN}

\section{Pengaruh Teh Hijau Terhadap Kadar Kolesterol Pengguna Kontrasepsi DMPA}

Hasil penelitian ini membuktikan bahwa tidak terdapat pengaruh teh hijau dalam menurunkan kadar kolesterol total. Banyak Penelitian menyatakan teh hijau mampu menurunkan kadar kolesterol diantaranya yang menyebutkan bahwa ada pengaruh pemberian teh hijau terhadap penurunan kadar kolesterol pada lansia awal (4655) tahun (Astari, 2017). Hal ini dukung pula oleh penelitian yang menyebutkan bahwa pemberian ekstrak teh hijau mampu menurunkan kadar kolesterol total. Pemberian ekstrak teh hijau lebih baik dalam memperbaiki profil lipid pada dislipidemia dan menurunkan kadar leptin pada tikus putih yang dipapar Depo Progestin (Tamon et al., 2021).

Pengaruh penggunaan jangka panjang dari DMPA yang telah menggunakan lebih dari 2 tahun menunjukkan bahwa kadar trigliserida, kolesterol total dan Low Density Lipoprotein (LDL) lebih tinggi sedangkan kadar Hight Density Lipoprotein (HDL) menurun. Hal ini disebabkan oleh progesterone yang terkandung dalam kontrasepsi dapat mempengaruhi kerja Hepatic Lipase (HL). Hepatic Lipase (HL) merupakan enzim yang membantu proses sekresi dari HDL - kolesterol, apabila kerja $\mathrm{HL}$ terhambat maka produksi $\mathrm{HDL}$ mengalami penurunan dan LDL mengalami peningkatan serta terjadi peningkatan pada trigliserida (Nigar et al., 2017). Kandungan Flavonoid pada teh hijau telah terbukti dapat memperbaiki profil lipid darah dan memiliki efek vasoprotektif juga memiliki kemampuan untuk menghambat CETP (Cholesteryl Ester Transfer Protein), sehingga dapat meningkatkan kadar kolesterol HDL dan menurunkan kadar kolesterol LDL (Susilawati et al., 2015).

Dalam penelitian ini pada kelompok teh hijau tidak terjadi penurunan kadar kolesterol secara bermakna karena kadar kolesterol total sangat dipengaruhi oleh asupan makanan. Masyarakat Karang Anyar memiliki tradisi rewang (membantu tetangga yang mengadakan hajatan dalam mengurus konsumsi dan lain sebagainya) sehingga mempengaruhi pola konsumsi makanan sehari-gari bagi responden. Hasil penelitian menunjukkan bahwa ada hubungan yang signifikan antara asupan lemak jenuh dengan kadar kolesterol darah. Kemudian hasil penelitian menunjukkan bahwa konsumsi tinggi asam lemak jenuh akan meningkatkan kadar kolesterol plasma. Menurut 
National Cholesterol Education Program (NCEP), menganjurkan untuk mengonsumsi asam lemak jenuh $<10$ persen total kalori dan jika kadar kolesterol masih tinggi dianjurkan untuk mengurangi sampai 7 persen dari total kalori.

Peningkatan kolesterol dalam darah disebabkan oleh faktor keturunan dan asupan lemak tinggi. Peningkatan konsumsi lemak jenuh dan kolesterol dapat meningkatkan konsentrasi kolesterol LDL. Lemak jahat seperti lemak jenuh dapat diubah menjadi kolesterol sehingga meningkatkan kadar kolesterol darah terutama LDL dengan cara menurunkan perombakan atau katabolismenya. Lemak tak jenuh bermanfaat menurunkan kadar kolesterol dalam darah. Faktor makanan yang berpengaruh terhadap kadar kolesterol darah adalah lemak total, lemak jenuh, dan energi total. Sumber utama lemak jenuh adalah lemak daging dan lemak susu yang terdapat dalam produk seperti susu, krim, mentega, keju, es krim, margarin, kuning telur, dan minyak tumbuhtumbuhan (minyak kelapa, minyak kelapa sawit, minyak kacang tanah, minyak kacang kedelai, dan sebagainya) (Yuliantini et al., 2015).

\section{Pengaruh Sari Kacang Hijau Terhadap Kadar Kolesterol Pengguna Kontrasepsi DMPA}

Hasil pengukuran kadar kolesterol total akibat penggunaan kontrasepsi DMPA pada kelompok sari kacang hijau didapatkan rerata sebelum perlakuan sebesar $252 \mathrm{mg} / \mathrm{dl}$, mengalami penurunan setelah diberikan sari kacang hijau dengan rerata $179 \mathrm{mg} / \mathrm{dl}$. Hasil penelitian ini sejalan dengan penelitian lain yang menyatakan bahwa kadar kolesterol sesudah mengkonsumsi sari kacang hijau lebih rendah dibandingkan sebelum mengonsumsi sari kacang hijau (Ndolu et al., 2020). Jus kacang hijau mampu menurunkan profil lipid (kolesterol total, HDL, LDL, trigliserida) pada pasien dislipidemia (Maulidya et al., 2018). Pemberian ekstrak kacang hijau terbukti berpengaruh terhadap penurunan kadar kolesterol total pada wanita hiperkolesterolemia. Jus kacang hijau pada pria hiperkolesteromia terbukti dapat menurunkan kadar kolesterol total.

Kacang hijau memiliki kandungan protein yang cukup tinggi, yaitu sebanyak $24 \%$. Di dalamnya terdapat sumber mineral penting antara lain kalsium dan fosfor yang bermanfaat untuk memperkuat tulang. Lemaknya merupakan asam lemak tak jenuh sehingga baik untuk jantung sehingga aman dikonsumsi karena kandungan lemaknya rendah. Protein dalam kacang hijau kaya akan asam amino esensial seperti leusin, isoleusin, dan valin. Protein dalam kacang hijau berperan sebagai antioksidan dan terlibat dalam metabolisme lipid. Leusin, isoleusin dan valin merupakan asam amino rantai cabang yang membantu menghambat sintesis dan absorpsi kolesterol dalam usus. Pemberian tauge sebagai produk olahan kacang hijau juga menurunkan kadar kolesterol (Sukmawati \& Asgap, 2017).

\section{Pengaruh Teh Hijau dan Sari Kacang Hijau Terhadap Kadar Kolesterol Pengguna Kontrasepsi DMPA.}

Hasil penelitian ini menunjukkan bahwa teh hijau yang dikonsumsi dengan sari kacang hijau yang dikonsumsi dalam waktu yang berbeda mampu menurunkan kadar kolesterol total pada akseptor KB DMPA di Desa Karang Anyar. Belum didapatkan penelitian yang menggabungkan pemberian teh hijau dan sari kacang hijau. Namun banyak penelitian yang meneliti tentang efek sari kacang hijau dan teh hijau terhadap kadar kolesterol yang diberikan secara terpisah pada kelompok yang berbeda. Beberapa penelitian mengenai pemberian jus kacang hijau pada wanita hiperkolesterolemia yang dikonsumsi $400 \mathrm{ml} / \mathrm{hari}$ selama 14 hari telah terbukti dapat menurunkan kolesterol total. Pemberian olahan susu kacang hijau mampu menurunkan kolesterol darah pada ayam Boiler (Dwiputra et al., 2018).

Berdasarkan uraian diatas, kacang hijau memiliki potensi untuk menurunkan kadar kolesterol total dalam darah. Jus kacang hijau merupakan salah satu jenis olahan kacang hijau dengan cara pengolahan yang sederhana dan mudah dikonsumsi. Kacang hijau memiliki kandungan protein yang cukup tinggi, yaitu sebanyak $24 \%$. Di dalamnya terdapat sumber mineral penting antara lain kalsium dan fosfor yang bermanfaat untuk memperkuat tulang. Protein dalam kacang hijau kaya akan asam amino esensial seperti leusin, isoleusin, dan valin (Kartika et al., 2019). Protein dalam kacang hijau berperan sebagai antioksidan dan terlibat dalam metabolisme lipid. Leusin, isoleusin dan valin merupakan asam amino rantai cabang yang membantu menghambat sintesis dan absorpsi kolesterol dalam usus (Meilina \& Afriana, 2019). Ekstrak teh hijau dapat mengubah profi I lipid yaitu penurunan kolesterol total, penurunan trigliserida, penurunan LDL, dan peningkatan $\mathrm{HDL}$ (Hardani et al., 2014).

Teh hijau terutama pada bagian daun mengandung komponen bioaktif seperti polifenol, flavonoid, asam amino, teaflavin, kafein, tearubigin, tanin, dan katekin. Kandungan katekin dalam teh varietas sinensis adalah katekin 0,07 gram $/ 100$ gram daun, terutama Epicatekin (EC) 1,13 


\section{JKM (Jurnal Kebidanan Malahayati),Vol 7,No.3.Juli 2021, \\ ISSN (Print) 2476-8944 ISSN (Online) 2579-762X, Hal 376-382}

gram/100 gram daun, Epikatekin Gallat (ECG) 1,35 gram/100 gram daun, Epigallokatekin (EGC) 2,38 gram/100 gram daun, dan Epigallokatekin Gallat (EGCG) 8,59 gram/100 gram daun, tanin 1,21 gram/ 100 gram daun, dan kafein 2,78 gram/ 100 gram daun. EGCG adalah katekin yang sangat kuat dengan sifatnya sebagai antioksidan, antihiperkolesterolemia, hipertensi, dan penyakit degeneratif lainnya (Anjarsari, 2016). Teh hijau berfungsi sebagai antioksidan yang menghambat stres oksidatif pada uterus dan ovarium akibat paparan DMPA (Nora Veri et al., 2015). Seduhan teh hijau juga melindungi pembuluh darah endometrium dari kerusakan (Emilda et al., 2017; N. Veri et al., 2019).

\section{SIMPULAN}

Tidak terdapat perubahan yang signifikan kadar kolesterol total pengguna KB suntik progestin atau DMPA antara sebelum dan sesudah diberikan teh hijau. Namun pemberian sari kacang hijau dan teh hijau yang dikombinasikan dengan sari kacang hijau mampu menurunkan kadar kolesterol tersebut secara bermakna.

\section{SARAN}

Perlu dilakukan penelitian lanjutan dengan mengontrol faktor perancu seperti pola makan sehari-hari.

\section{DAFTAR PUSTAKA}

Anjarsari, I. R. D. (2016). Katekin teh Indonesia: prospek dan manfaatnya. Kultivasi, 15(2), 99-106. https://doi.org/10.24198/kltv.v15i2.11871

Astari, N. M. S. N. (2017). Pengaruh Pemberian Teh Hijau Terhadap Penurunan Kadar Kolesterol Pada Lansia Awal (46-55) Tahun. Repository.

Dwiputra, R., Adriani, L., \& Permana, R. (2018). Pengaruh Penambahan Probiotik Berbasis Susu Sapi, Susu Kedelai Dan Susu Kacang Hijau Dalam Ransum Terhadap Kadar Kolesterol Dan Trigliserida Darah Ayam Broiler. Jurnal Nutrisi Ternak Tropis Dan IImu Pakan, 2(September), 135-144.

Emilda, A. S., Veri, N., \& Alchalidi, A. (2017). High dose of green tea infusion normalized spiral artery density in rats treated with the depotmedroxyprogesterone acetate. Journal of Intercultural Ethnopharmacology. https://doi.org/10.5455/jice.20160928012442

Fazdria, F. (2020). Teh Hijau Menurunkan Kadar Koleterol Total Pada lbu Akseptor KB Depomedroxyprogesterone Acetate (DMPA).
Jurnal Kebidanan Malahayati, 6(4), 531-536. https://doi.org/10.33024/jkm.v6i4.3028

Fernández-Friera, L., Fuster, V., López-Melgar, B., Oliva, B., García-Ruiz, J. M., Mendiguren, J., Bueno, H., Pocock, S., Ibáñez, B., Fernández-Ortiz, A., \& Sanz, J. (2017). Normal LDL-Cholesterol Levels Are Associated With Subclinical Atherosclerosis in the Absence of Risk Factors. Journal of the American College of Cardiology, 70(24), 2979-2991.

https://doi.org/10.1016/j.jacc.2017.10.024

Hardani, E., Lestariana, W., \& Susetyowati, S. (2014). Efek pemberian ekstrak teh hijau (Camellia sinesis (L) O. Kuntze) var. Assamica terhadap total lemak tubuh dan profil lipid wanita dewasa overweight dan obesitas. Jurnal Gizi Klinik Indonesia, 10(4), 209-217. https://doi.org/10.22146/ijcn.18874

Kartika, H. Y., Darawati, M., Widiada, I. G. N., \& Jaya, I. K. S. (2019). Pengaruh penambahan Kacang Hijau (Vigna radiata) terhadap sifat organoleptik, kadar zat gizi dan daya terima Kahimela Bars. Jurnal Gizi Prima, 4(1), 1623.

mataram.ac.id/index.php/home http://jgp.poltekkes-

Kemenkes RI. (2017). Profil Penyakit Tidak Menular Tahun 2016. In Kementerian Luar Negeri RI (Vol. 1, Issue 1).

Maulidya, R., Wiboworini, B., \& Sugiarto, S. (2018). Pengaruh Pemberian Jus Kacang Hijau Terhadap Profil Lipid Darah Pada Pasien Dislipidemia Rawat Jalan. Jurnal Kesehatan Kusuma Husada, 9(2), 127-133. https://doi.org/10.34035/jk.v9i2.271

Maydawati, V., \& Veri, N. (2020). Potensi Teh Hijau Dalam Menurunkan Kadar Kolesterol Pada Akseptor Kontrasepsi Progestin Hiperkolesterolemia. Journal of Healthcare Technology and Medicine, 6(2), 1031. https://doi.org/10.33143/jhtm.v6i2.1089

Meilina, R., \& Afriana, S. (2019). Efek Antiinflamsi Gel Kacang Hijau Pada Mencit Putih (Mus musculus). Journal of Healthcare Technology and Medicine, 5(2), 231. https://doi.org/10.33143/jhtm.v5i2.422

Munabari, F., \& Ikawati, K. (2018). Pengaruh Pemberian Sari Kacang Hijau Terhadap Kadar Kolesterol. Prosiding HEFA (Health Events for All), PROSIDING(1), 89-100. http://prosiding.stikescendekiautamakudus.ac .id/index.php/pros/article/view/330

Ndolu, R., Manafe, D., \& Lada, C. (2020). Pengaruh Pemberian Ekstrak Kecambah Kacang Hijau Terhadap Kadar Kolesterol Total Serum Tikus 
(Rattus Norvegicus) Galur. Cendana Medical Journal, 2(20), 214-221. http://ejurnal.undana.ac.id/CMJ/article/view/3 491

Nigar, S., Fatima, I., \& Haq, A. A. (2017). Effects of medroxy progesterone acetate (Injectable Contraceptive) on Endometrium (Uterus) of Adult Albino Rats. Medical Forum Monthly, 28(6), 140-143.

Prasetyorini, T., Islami, Y. H., Fajrunni'mah, R., \& Karningsih, K. (2021). Hubungan Antara Lama Penggunaan Kontrasepsi Suntik Depo Medroxy Progesteron Acetate (DMPA) dengan Kadar Kolesterol Total pada Akseptor KB. Muhammadiyah Journal of Midwifery, 1(2), https://doi.org/10.24853/myjm.1.2.37-44

Prawerti, W., Runiari, N., \& Ruspawan, M. (2019). Lama Pemakaian Kontrasepsi Suntik Depo Medroksiprogesteron Asetat Dengan Kadar Kolesterol Pada Akseptor KB. Jurnal Gema Keperawatan, 12(1), 93-106.

Rahayu, F., Jose, C., \& Haryani, Y. (2015). Total Fenolik, Flavonoid, dan Aktivitas Antioksidan Dari Produk Teh Hijau dan Teh Hitam Tanaman Bangun-Bangun (Coleus Amboinicus) dengan Perlakuan Ett Rumput Paitan. Jom Fmipa.

Riskesdas, K. (2018). Riset Kesehatan Dasar Nasional. Kementerian Kesehatan RI.

Steyers, C. M., \& Miller, F. J. (2014). Endothelial dysfunction in chronic inflammatory diseases. International Journal of Molecular Sciences, 15(7), 11324-11349. https://doi.org/10.3390/ijms150711324

Sukmawati, S., \& Asgap, A. R. P. (2017). Uji Efek
Jus Taoge Terhadap Kadar Kolesterol Tikus (rattus norvegicus) Jantan Hiperlipidemia. Jurnal ilmiah as-syifaa, 9(2), 188-194. https://doi.org/10.33096/jifa.v9i2.301

Susilawati, E., Barlianto, W., \& Wayan Arsana Wiyasa, I. (2015). Cholesterol/HDL-C ratio lowering effect of green tea in rats exposed to depot medroxiprogesterone acetate. Journal of Experimental and Integrative Medicine. https://doi.org/10.5455/jeim.140915.br.025

Tamon, B. T., Tiho, M., \& Kaligis, S. H. M. (2021). Efek Antioksidan pada Teh Hijau terhadap Kadar Kolesterol Darah. EBiomedik, 9(2), 151-159.

Veri, N., AS, E., Mutiah, C., Seriana, I., \& Malinda, R. (2019). Protective Effect Of Green Tea On Tunica Adventitia And Endothelial Changes Resulting From Depot Medroxy Progesterone Acetate. Journal of Taibah University Medical Sciences, $14(1)$. https://doi.org/10.1016/j.jtumed.2018.10.002

Veri, Nora, Aulia, F., Ratnawati, R., Hidayati, D. Y. N., Noorhamdani, N., \& Dwijayasa, P. M. (2015). Protective effect of green tea against ovarian and endometrial apoptoses in rats treated with depot medroxyprogesterone acetate. Biomarkers and Genomic Medicine. https://doi.org/10.1016/j.bgm.2015.04.002

Wahyuni, E. S., \& Putri, A. K. (2017). Upaya Mencegah Efek Samping Penggunaan Kontrasepsi Depo Progestin Dengan Ekstra Teh Hijau. XV(1), 87-97.

Yuliantini, E., Sari, A. P., \& Nur, E. (2015). Hubungan asupan energi, lemak dan serat. Nutrition and Food Research, 38(2), 139147. 